\title{
Childhood nephrotic syndrome -a single centre experience in Althawra central hospital,Albaida- Libya during 2005-2016
}

\begin{abstract}
The aim of this study is to determine response to treatment in terms of remission and relapse, related risk factors, type of management and complications of nephrotic syndrome among studied patients.

Design: Retrospective, analytical study.

Setting: Pediatric nephrology clinic at Althawra Central Teaching Hospital-Albida,

Participants/patients: All patients with idiopathic nephrotic syndrome (INS) were evaluated during 2005- 2016. Patients divided into two groups, group I $46(39 \%)$ is non-relapse and group II $72(62.7 \%)$ is relapse group. Group II are sub divided into group A: frequent relapse steroid dependent (FRNS/SDNS) and group B: infrequent relapse nephrotic syndrome (IRNS).

Results: Records of 118 children with INS were studied and 74 (62.7\%) were boys, male to female ratio $1.7: 1$. There was no significance difference between group I and group II in the following parameters; age group, sex, family history, initial hypertension and hematuria ( $\mathrm{p}$ value $=>0.05$ ). Mean proteinuria was significantly higher in group II ( $\mathrm{p}=0.001)$, while mean S. albumin, mean $\mathrm{s}$. cholesterol and mean blood urea did not show any significant difference statistically and $p$ value were $(0.022),(0.012),(0.116)$ respectively. Group B showed significant higher frequency than group A regarding sex $(\mathrm{p}=0.010)$, age group 1 and positive family history $(\mathrm{p}=0.050)$, both groups were comparable regarding gross hematuria and hypertension $(\mathrm{p}=0.975)$. Mean S. albumin was significantly low in group $\mathrm{A}(\mathrm{p}=0.03)$ but no significance difference between both group regarding mean proteinuria, lipid profile and renal function and the $\mathrm{p}$ value for the three variables were $(0.015)(0.206)(0.257)$ respectively. The most common complications were hypocalcemia, cushingoid facies and obesity $(26.5 \%, 25.4 \%$, $18.6 \%)$ respectively, followed by infections $(13.5 \%)$, hypertension $(11.8 \%)$, acute kidney injury $(8.4 \%)$, chronic kidney disease $(1.7 \%)$ and death in one patient $(0.8 \%)$.

Conclusion: Idiopathic nephrotic syndrome is chronic relapsing disease for most steroid-responsive patients especially males between $2-8$ years with different complications of disease and its treatment affecting patient's life.
\end{abstract}

Keywords: Idiopathic nephrotic syndrome, relapse, steroid sensitive nephrotic syndrome, steroid resistant nephrotic syndrome, nephrotic-range proteinuria, edema, hyperlipidemia, hypoalbuminemia, remission, relapses, cyclosporine, chlorambucil, cyclophosphamide
Volume 6 Issue 6 - 2018

\section{Mabrouka A M Bofarraj,' Fatma S Ben \\ Khaial,' Najwa H Abduljawad,' Rima \\ Alshowbki}

'Department of Pediatric Medicine, Al Thawra Central Teaching Hospital, Libya

${ }^{2}$ Department of Family and Community Medicine, Faculty of Medicine, Benghazi University, Libya

Correspondence: Mabrouka A M Bofarraj, Department of Pediatric Medicine, Al Thawra Central Teaching Hospital, Faculty of medicine, Omar Al Moukhtar University,Albaida-Libya,Te 00218927445625,Email bofarralm@gmail.com

Received: October 24, 2018 | Published: November 23, 2018
Abbreviations: SSNS, steroid-sensitive nephrotic syndrome; SRNS, steroid-resistant nephrotic syndrome; ISKDC, international study of kidney disease in children; MCNS, minimal change nephrotic syndrome; FSGS, focal segmental glomerulosclerosis; KDIGO, kidney disease improving global outcomes; FRSD, frequent relapse steroid dependent; IFNS, infrequent relapse nephrotic syndrome; SSPS, statistical package for social sciences

\section{Introduction}

Pediatric nephrotic syndrome, known as nephrosis and is defined by the presence of nephrotic-range proteinuria, edema, hyperlipidemia, and hypoalbuminemia. ${ }^{1}$ Nephrotic-range proteinuria in children is protein excretion of more than $40 \mathrm{mg} / \mathrm{m}^{2} / \mathrm{h}^{1} \mathrm{INS}$ and is divided into steroid-sensitive nephrotic syndrome (SSNS) and steroidresistant nephrotic syndrome (SRNS) because response to steroids has a high correlation with histological subtype and prognosis. ${ }^{2}$ The International Study of Kidney Disease in Children (ISKDC), found that the vast majority of preadolescent children with INS had minimal change nephrotic syndrome (MCNS) on kidney biopsy. Whereas $90 \%$ of children with MCNS responded to corticosteroid treatment with remission of their nephrotic syndrome and only $20 \%$ of children with focal segmental glomerulosclerosis (FSGS) responded to steroids. ${ }^{2,3}$ Specific treatment of nephrotic syndrome depends on its type; Kidney Disease Improving Global Outcomes (KDIGO) guidelines in 2012 that include recommendations on treatment of nephrotic syndrome in adults and children. ${ }^{4}$ Despite the generally favorable prognosis in patients who respond to steroids, the ISKDC reported a $60 \%$ rate of subsequent relapses, which can lead to complications, increased morbidity, and decreased quality of life. ${ }^{3} \mathrm{~A}$ longer course of initial steroid treatment (12 week rather than the original ISKDC protocol 
of 8 week) may reduce the rate of subsequent relapse to $36 \%$ which still represents a large percent of patients who undergo repeated courses of immunosuppressant medications other than steroids (i.e., cyclosporine, chlorambucil, cyclophosphamide) with possible co morbidities and more serious side effect. ${ }^{5,6}$ In fact relapse or remission in nephrotic syndrome is important outcome which reflect the prognosis of treated patients. The periodic follow up of these patients is essential to evaluate the extent of the success of management provided to the patients. The aim of this study is to determine response to treatment in terms of remission and relapse, related risk factors, type of management and complications of nephrotic syndrome among studied patients.

\section{Patient and methods}

An analytical retrospective study was conducted on children diagnosed as INS presented to Nephrology clinic Al Thawra Central Teaching Hospital. Medical records of these patients were reviewed from January. 2005 to December 2016. In this study NS was diagnosed according to the criteria of the international study of kidney disease in children (ISKDC). Patients were categorized into two groups: Group I that contains 46 patients (no relapses) and Group II contain 72 patients (with relapses). Group II were subdivided into group A frequent relapse steroid dependent (FRSD), group B infrequent relapse nephrotic syndrome (IFNS).

Demographic characteristics include gender, age investigations that include: total protein, S. albumin, S. cholesterol, renal function test (Urea, S. creatinine), urine 24 protein $\mathrm{g} /$ day, history of hematuria, hypertension, family history of nephrotic syndrome, complications, management, outcomes (Remission \& Relapses), steroid response (sensitive, resistance or dependent to cytotoxic therapy, other drug and frequency of relapses (frequent and infrequent) were recorded. Relapse is considered when the patients have development of edema and persistent of urinary protein excretion $>40 \mathrm{mg} / \mathrm{m}^{2} / \mathrm{hr}, 3+$ by dipstick for 3 consecutive days. Remission is considered where the patients have urine protein negative to trace for 3 consecutive days. Frequent relapses was defined as the occurrence of $\geq 2$ relapses in 6 months or $\geq 3$ relapses in 12 months, and steroid dependence as the presence of two consecutive relapses while on tapering doses of prednisolone. ${ }^{7}$ Failure to show remission of proteinuria despite 4-weeks treatment with prednisolone $(2 \mathrm{mg} / \mathrm{kg} /$ day $)$ was termed as initial resistance when noted at onset of disease, and late resistance if occurring in a patient previously responsive to steroids. ${ }^{7}$ The disease course, use of alternative therapies and complications were described for patients with minimum 12-months follow up at this center (Study Group). The course of disease during these 12 months was categorized as single episode, infrequent relapses, frequent relapses, steroid dependence or resistance.

\section{Therapy course}

Adequate initial treatment for first episode was used prednisolone ( $2 \mathrm{mg} / \mathrm{kg} /$ day) for $\geq 4$ weeks followed by $1.5 \mathrm{mg} / \mathrm{kg}$ on alternate days for $\geq 4$ weeks and tapering the dose for 3 to 4 months. Relapses were treated with prednisolone, $2 \mathrm{mg} / \mathrm{kg} / \mathrm{d}$ until remission and $1.5 \mathrm{mg} /$ $\mathrm{kg}$ on alternate days for 4 weeks. Patients with frequent relapses or steroid dependence received prednisolone $(0.3-0.7 \mathrm{mg} / \mathrm{kg})$ on alternate days for 9-12 months. Those having relapses or steroid toxicity received one or more alternative agents. ${ }^{7}$ In this study Mendoza protoclol (high dose methyl prednisolone infusion), cytotoxic chemotherapy drugs (cyclosporin, cyclophosphamid) and levamisol were included as alternative agents after 2010 and lastly adding MMF (mycophenolatemofetil) in 2014.
Often as follows:

a. levamisole ( $2 \mathrm{mg} / \mathrm{kg}$ on alternate days for 6 months $)$

b. oral cyclophosphamide ( $2 \mathrm{mg} / \mathrm{kg} / \mathrm{d}$ for 12 weeks)

c. $\operatorname{MMF}(600-1000 \mathrm{mg} / \mathrm{m} 2 / \mathrm{d})$

d. cyclosporine $(4-6 \mathrm{mg} / \mathrm{kg} / \mathrm{d}){ }^{8}$

Kidney biopsies were not done because of unavailability except for few patients who were sending abroad.

\section{Data analysis}

Data entry statistical analysis and calculations were performed with the use of Statistical Package for Social sciences (SSPS). The data interpreted in table and figures, the numerical data were shown as percent, mean + Standard Deviation. To find the significant difference between the studied variable, Chi-Square test and unpaired "t" test were used, $p$ value $<0.05$ was taken as level of significance.

\section{Results}

118 children diagnosed as INS, 74(63\%) patients were males and $44(37 \%)$ were females, male to female's ratio1.7:1. The age group was divided into two groups: group 1 (2- 8 years) which represented $(82 \%)$ and group $2(<2$ years or $>8$ years $)$ were represented $(18 \%)$. Among the total studied children 39\% showed no relapse, $30 \%$ had frequent relapse and $31 \%$ with infrequent relapse (Figure 1). Initial steroid resistance (SRNS) was noted in 4 patients $(3.38 \%)$ and 114 patients $(96.6 \%)$ were sensitive (Figure 2). Baseline characteristics at initial presentation showed group I (39\%) no relapse and group II relapses (61\%)and both groups compared with no significant statistical difference regarding age at initial presentation gender, family history hypertension and gross hematuria $(\mathrm{p}=0.795)$. Mean proteinuria $(24$ hour protein excretion) was significantly higher in group II ( $\mathrm{p}=0.001)$, while mean S. albumin, mean S. cholesterol and mean blood urea did not show any statistical significance $P$ value $(0.022,0.012,0.116)$ respectively. Group II (relapses patients) were divided into two subgroups, group A (frequent relapse $n=35$ ) and group B (infrequent relapses $\mathrm{n}=37$ ) showed risk factors for disease course compares the clinical and laboratory characteristics of both groups (Table 1). There was a significantly higher frequency in group $\mathrm{B}$ for males, age group 1 and native family history than in $\operatorname{group} \mathrm{A}(\mathrm{p}=0.010),(\mathrm{p}=0.05),(\mathrm{p}=0.05)$ respectively, both groups were comparable regarding Hematuria and hypertension ( $\mathrm{p}=0.975)$. Mean $\mathrm{S}$. albumin significantly low in group $A(p=0.03)$ but no significance difference statistically between both group regarding mean proteinuria, lipid profile and renal function and $\mathrm{p}$ value (0.015) (0.206) (0.257) respectively as shown in Table 2 . All patients had received first line adequate initial therapy with oral prednisolone treatment and almost one-half of the patients $(54 \%)$, who were followed are required alternative medications for frequent relapses, steroid dependent and steroid resistant (Table 2).

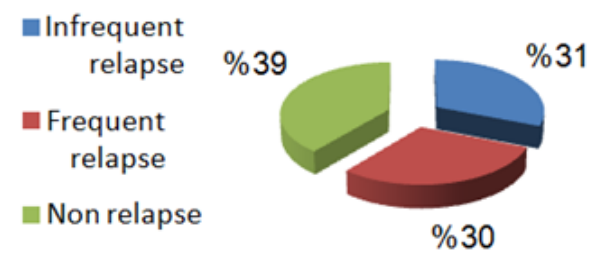

Figure I Distribution of Relapses of studied children during studied period 


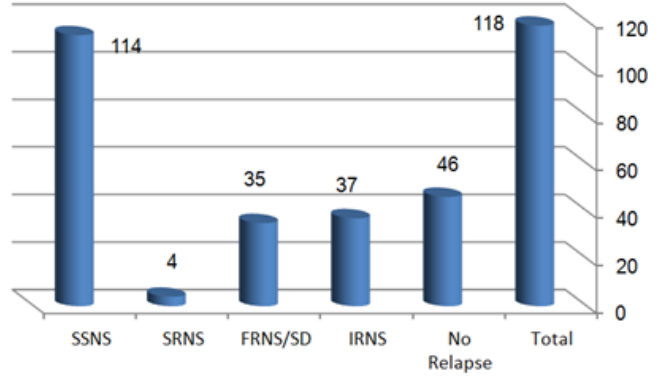

Figure 2 Distribution of idiopathic nephrotic syndrome in relation to response and relapse

Note: FRNS, frequent relapse nephrotic syndrome; IRNS, infrequent relapse nephrotic syndrome; SDNS, steroid dependent nephrotic syndrome; SRNS, steroid resistant nephrotic syndrome

Table I Demographic and laboratory data of idiopathic nephrotic syndrome in relation to relapse

\begin{tabular}{|c|c|c|c|c|}
\hline Variable & Parameter & $\begin{array}{l}\text { Group I } \\
\text { no relapse } \\
\text { No=46 } \\
(39 \%)\end{array}$ & $\begin{array}{l}\text { Group II } \\
\text { relapse } \\
\text { No=72 } \\
(61 \%)\end{array}$ & $\begin{array}{l}P \\
\text { value }\end{array}$ \\
\hline \multirow[t]{2}{*}{ Sex } & Male & 30 & 46 & 0.975 \\
\hline & Female & 16 & 26 & \\
\hline \multirow[t]{2}{*}{ Age } & Groupl & 37 & 60 & 0.975 \\
\hline & Group2 & 9 & 12 & \\
\hline \multirow[t]{2}{*}{ Family history } & Yes & 2 & 4 & 0.975 \\
\hline & No & 44 & 68 & \\
\hline \multirow[t]{2}{*}{ HTN } & Yes & 5 & II & 0.975 \\
\hline & No & 41 & 61 & \\
\hline \multirow[t]{3}{*}{ Hematuria } & Yes & 6 & 8 & 0.975 \\
\hline & No & 38 & 56 & \\
\hline & No data & 2 & 8 & \\
\hline Proteinuria & $\begin{array}{l}\text { mean } \\
\text { proteinuria } \\
(\mathrm{g} / 24 \mathrm{hr})\end{array}$ & $4.2 \pm 0.7$ & $4.815 \pm 1.44$ & 0.001 \\
\hline Hypoalbuminemia & $\begin{array}{l}\text { mean } \mathrm{S} \text {. } \\
\text { albumin }(\mathrm{g} / \mathrm{l})\end{array}$ & $4.7 \pm 23.4$ & $2.11 \pm 0.810$ & 0.223 \\
\hline Lipid profile & $\begin{array}{l}\text { mean serum } \\
\text { cholesterol } \\
(\mathrm{mg} / \mathrm{dl})\end{array}$ & $320.5 \pm 91.5$ & $340.17 \pm 82.7$ & 0.122 \\
\hline RFT & $\begin{array}{l}\text { mean blood } \\
\text { urea }(\mathrm{mg} / \mathrm{dl})\end{array}$ & $29.88 \pm 19.94$ & $25.88 \pm 12.92$ & 0.116 \\
\hline
\end{tabular}

Note: HTN, Hypertension; RFT, renal function test; Proteinuria: urine 24 protein g/day.

Table 2 Factors affect types of relapsing patients

\begin{tabular}{lllll} 
& & Group A & Group B & \\
& & $\begin{array}{l}\text { FRNS, } \\
\text { SDNS }\end{array}$ & IRNS & \\
Variable & Parameter & No=35 & No=37 & $\begin{array}{l}\text { P } \\
\text { value }\end{array}$ \\
\hline Sex & Male & 17 & 29 & 0.01 \\
\hline
\end{tabular}

\begin{tabular}{|c|c|c|c|c|}
\hline \multirow[b]{3}{*}{ Variable } & \multirow[b]{3}{*}{ Parameter } & \multirow{3}{*}{$\begin{array}{l}\text { Group A } \\
\text { FRNS, } \\
\text { SDNS } \\
\text { No=35 }\end{array}$} & \\
\hline & & & IRNS & \\
\hline & & & $\mathrm{No}=37$ & $\begin{array}{l}P \\
\text { value }\end{array}$ \\
\hline & Female & 18 & 8 & \\
\hline \multirow[t]{2}{*}{ Age } & group I & 28 & 34 & 0.05 \\
\hline & group2 & 7 & 3 & \\
\hline \multirow[t]{2}{*}{ Family history } & Yes & 4 & 9 & 0.05 \\
\hline & No & 31 & 28 & \\
\hline \multirow[t]{2}{*}{ HTN } & Yes & 5 & 6 & 0.975 \\
\hline & No & 30 & 31 & \\
\hline \multirow[t]{3}{*}{ Hematuria } & Yes & 6 & 2 & 0.975 \\
\hline & No & 27 & 23 & \\
\hline & No data & 2 & 12 & \\
\hline Proteinuria & $\begin{array}{l}\text { mean } \\
\text { proteinuria } \\
\left(\mathrm{mg} / \mathrm{m}^{2} / \mathrm{hr}\right)\end{array}$ & $4.27 \pm 1.35$ & $4.53 \pm 1.94$ & 0.015 \\
\hline Hypoalbuminemia & $\begin{array}{l}\text { mean } \mathrm{S} . \\
\text { albumin } \\
(\mathrm{mg} / \mathrm{dl})\end{array}$ & $0.68 \pm 0.71$ & $1.88 \pm 21.82$ & 0.03 \\
\hline lipid profile & $\begin{array}{l}\text { mean } \mathrm{S} \text {. } \\
\text { cholesterol } \\
(\mathrm{mg} / \mathrm{dl})\end{array}$ & $90.32 \pm 96.35$ & $\begin{array}{l}335.34 \\
\pm 87.66\end{array}$ & 0.206 \\
\hline RFT & mean urea & $20.62 \pm 20.401$ & $\begin{array}{l}26.99 \\
\pm 16.21\end{array}$ & 0.257 \\
\hline
\end{tabular}

Complications: Hypocalcemia, cushingoid facies and obesity represent $(26.2 \%)(25.4 \%) \quad(18.6 \%)$ respectively, followed by infections (13.5\%), hypertension (11.8\%), acute renal failure in (8.4\%), renal impairment was observed in (1.7\%) and death in one patient $(0.8 \%)$ (Table 3). Distribution of complications according to type of relapses nephrotic syndrome patients with no significant difference regarding hypertension for all groups $(p=0.100)$ but significantly higher frequency observed with frequent relapse steroid dependent nephrotic syndrome patients and $\mathrm{p}$ value $(0.050)$ each for renal failure, hypocalcaemia and highly significant $(0.001)$ for peritonitis (Table 4).

Table 3 Complications of idiopathic nephrotic syndrome and/or steroid therapy among the study population during follow-up of the disease

\begin{tabular}{lcc}
\hline Variable & No & $\%$ \\
\hline Hypocalcemia & 31 & 26.2 \\
Cushingoid facies & 30 & 25.4 \\
Infections & 16 & 13.5 \\
Hypertension & 14 & 11.8 \\
Overweight (obesity) & 22 & 18.6 \\
Hyperglycemia & 2 & 1.7 \\
Growth retardation & 12 & 10.1 \\
Acute renal failure & 10 & 8.4 \\
Chronic renal failure & 2 & 1.7 \\
Death & $\mathrm{I}$ & 0.8 \\
\hline
\end{tabular}


Table 4 Distribution of complication according to type of relapse nephrotic syndrome patients

\begin{tabular}{llllll}
\hline Complication & No relapse & IRNS & $\begin{array}{l}\text { FRNSI } \\
\text { SDNS }\end{array}$ & Total & \\
\hline a- HTN & 3 & No=37 & No=35 & I I 8 & $\begin{array}{l}\text { P } \\
\text { value }\end{array}$ \\
b- Renal failure & 1 & 6 & 5 & 14 & 0.1 \\
c- Low S. ca & 10 & 3 & 6 & 10 & 0.05 \\
d- Peritonitis & 1 & 8 & 13 & 31 & 0.05 \\
\hline
\end{tabular}

\section{Discussion}

The findings of the current study support previous published reports that childhood NS is a disease of high morbidity and results in significant healthcare burden. ${ }^{9}$ INS has highly variable therapeutic managements. Obtaining and maintaining the lowest level of proteinuria, will result in the best quality and quantity of both renal and patient survival. ${ }^{10}$ The characteristics of our patients were similar to that reported previously including age at onset, male preponderance and low incidence of familial cases. ${ }^{12,13}$ The extreme age of (age group 2 ) at presentation of NS in our study was represent (18\%), not too far from that reported on a group of children from Saudi Arabia (16.9\%). ${ }^{15}$ The disease was classified based on steroid response and frequency of relapse would be a predictor of increased hospitalizations and complications, as it is an important determinant of disease prognosis. This was substantiated in our analysis on hospitalizations. FRNS/ SDNS and SRNS were associated with increased hospitalization rates compared to children with SSNS. In our analysis observed $96.6 \%$ were sensitive and the proportion of patients having initial steroid resistance (SRNS) was noted in 4 patients (3.38\%) comprising lower proportion of initial resistance was $12.5 \%$ seen other studies. ${ }^{16-18}$ Long-term follow up of studied children $39 \%$ showed no relapse, $31 \%$ with infrequent relapse and 30\% had frequent relapse which in closer extremity to report of ISKDC reported that just $28.1 \%$ patients show frequent relapses in the first 6 months of their illness, ${ }^{16}$ Data from other centers, comprising relatively more than our observation, shows that the proportion of frequent relapses varies from $56-68 \% .{ }^{19-21}$

Children who experienced NS relapse were younger in the present study; the difference was not statistically significant. The lack of any association between age at onset of NS and occurrence of relapse has been reported by other workers. ${ }^{22,23}$ Similarly, gender and microscopic hematuria enjoy an inconsistent relationship with subsequent relapses, FR or SD in published literature..$^{22,24}$ while Andersen ${ }^{19}$ and Suresh Kumar $^{22}$ reported that male gender as risk factor for subsequent relapses, FR or SD, others did not find such relationship which doesn't agree with our results we found the opposite as females had higher percentage in FR /SD with statistical significance, the reasons for the inconsistency are unknown but may be related to differences in the study population and design. ${ }^{23,25}$ Our findings support previous published reports that childhood NS is a disease of high morbidity and Hematuria was found in $11.9 \%$ of our patients, which is much less than what was found by Thabet ${ }^{26}$ (63.6\%), Ibadin ${ }^{27}(60 \%)$ and Begum ${ }^{28}(45 \%)$. The percentage of Hypertension in the current study was $13.56 \%$ which lesser than other figures reported by Thabet ${ }^{26}$ study (26.8\%), Ibadin ${ }^{27}$ study (41.4\%), Begum $^{28}(50 \%)$ and Srivastava ${ }^{29}$ were seems to have little effect on the rate of relapse. In this study, patients had normal renal function with no significant difference in blood urea between both relapsed and non relapsed groups. Impaired renal function in accordance to the age and sex were observed in $26.7 \%$ in Thabet ${ }^{26}$ study and $19 \%$ of patients in Begum ${ }^{28}$ study. Takeda ${ }^{30}$ and Sarker ${ }^{31}$ found that, the mean serum albumin level in frequent relapse NS group was significantly lower than that of infrequent relapse NS group which seen in agreement with our results. In this study, complication related to the disease itself as Hypocalcaemia was found the same in the literature; ${ }^{32}$ that explained by lack of 25-hydroxycholecalciferol (the way that vitamin $\mathrm{D}$ is stored in the body) which may lost in the urine or may be relative hypocalcaemia due to hypoalbuminemia as ionized calcium is bound to albumin also other complication related to long-term corticosteroid therapy which increased risk of steroid toxicity including cushingoid features and infections were observed which follow the similar trend in the literature. ${ }^{32}$ Only one patient died in the current study represent $0.8 \%$ which was found the same report by Cohort $^{33}$ study but lesser than other studies reported by Wingen ${ }^{34}$ that found 10 deaths was resulting a mortality rate of $1.9 \%$ and $17 \%$ reported by $\mathrm{Wynn}^{35}$. From the analysis of this work compared to the published studies, one can notice similarities and differences between the reported data, and this may be explained by different design of different studies and could be due small sample size. A larger cohort study is required for a better understanding of these factors and advance management.

\section{Conclusion}

Idiopathic nephrotic syndrome is chronic relapsing disease for most steroid-responsive patients especially males between $2-8$ years with different complications of disease and its treatment affecting patient's life. Recommendations: Daily prednisolone during episodes of upper respiratory infections remains a relevant intervention aimed to reduce the risk of relapse, also zinc supplements which reduce both the frequency of respiratory tract infections and relapse rates. Prompt search and treatment for URTI should not be overlooked by clinicians managing children with nephrotic syndrome. These relapse-specific interventions can reduce the morbidity associated with frequent relapses and ultimately improve the child's quality of life.

\section{Acknowledgments}

We wish to thank the nephrology clinic nurses at Althawra central teaching hospital for providing the medical records of our patients and to thank Dr Marfoaa S Ali, Dr Salema R Qowaider for their help and Dr Naziha R Rhuma for her help and cooperation and special thank to Professor Ihab El-Hakim, for his constant support.

\section{Conflicts of interests}

Author declares that there is no conflicts of interests.

\section{References}

1. Dunphy $\mathrm{M}$, Winland $\mathrm{J}$, Porter $\mathrm{T}$, et al. In classic forms of glomerulonephrosis, nephrotic syndrome develops, and various degrees of proteinuria may be present. Primary Care FA Davis. 2015.634p.

2. International study of kidney disease in children (iskdc). nephrotic syndrome in children: prediction of histopathology from clinical and laboratory characteristics at time of diagnosis. a report of the international study of kidney disease in children. Kidney Int. 1978;13(2):159-165.

3. International study of kidney disease in children (iskdc). the primary nephrotic syndrome in children. identification of patients with minimal change nephrotic syndrome from initial response to prednisone. a report of the international study of kidney disease in children. $J$ Pediatr. 1981;(4):561-564.

4. Kidney disease improving global outcomes. kdigo clinical practice guideline for glomerulonephritis. Kidney International Supplements. 


\section{2;2 Suppl 2:139-274.}

5. Ehrich JH, Brodehl J. Long versus standard prednisone therapy for initial treatment of idiopathic nephrotic syndrome in children. ArbeitsgemeinschaftfürPädiatrische Nephrologie. Eur $J$ Pediatr. 1993;152(4):357-361.

6. Ruth EM, Kemper MJ, Leumann EP, et al. Children with steroidsensitive nephrotic syndrome come of age: long-term outcome. $J$ Pediatr. 2005;147(2):202-207.

7. Bagga A, Ali U, Banerjee S. Indian pediatric nephrology group, indian academy of pediatrics. management of steroid sensitive nephrotic syndrome: revised guidelines. Indian Pediatr. 2008;45(3):203-214.

8. International study of kidney disease in children. primary nephrotic syndrome in children: clinical significance of histopathologic variants of minimal change and of diffuse mesangial hypercellularity. Kidney Int. 1981;20:765-771.

9. Eddy AA, Symons JM. Nephrotic syndrome in childhood. Lancet 2003;362(9384):629-639.

10. Cattran DC, Alexopoulos E, Heering P, et al. Cyclosporin in idiopathic glomerular disease associated with the nephrotic syndrome: Workshop recommendations. Kidney Int. 2007;72(12):1429-1447.

11. Abeyagunawardena AS, Dillon MJ, Rees L, et al. The use of steroidsparing agents in steroid sensitive nephrotic syndrome. Pediatr Nephrol. 2003;18(9):919-924

12. Report of the international study of kidney disease in children. early identification of frequent relapsers among children with minimal change nephrotic syndrome. a report of the international study of kidney disease in children. J Pediatr. 1982;101(4):514-518.

13. Srivastava RN, Mayekar G, Anand R, et al. Nephrotic syndrome in Indian children. Arch Dis Child. 1975;50(8):626-630.

14. Bakkali LE, Pereira RR, Kuik DJ, et al. Nephrotic syndrome in the Netherlands: a population based cohort study and a review of the literature. Pediatr Nephrol. 2011;26(8):1241-1246.

15. Pradhan SK, Sivaraj P, Das L, et al. Spectrum of clinico-pathologica profile and treatment response in children with nephrotic immunoglobulin a nephropathy. Saudi J Kidney Dis Transpl. 2015;26(4):708-711.

16. Tarshish P, Tobin JN, Bernstein J, et al. Prognostic significance of the early course of minimal change nephrotic syndrome: Report of the International Study of Kidney Disease in Children. J Am Soc Nephrol. 1997;8(5):769-776

17. Koskimies O, Vilska J, Rapola J, et al. Long-term outcome of primary nephrotic syndrome. Arch Dis Child. 1982;57(7):544-548.

18. Srivastava RN, Agarwal RK, Moudgil A, et al. Late resistance to corticosteroids in nephrotic syndrome. J Pediatr. 1986;108(1):66-70.

19. Andersen RF, Thrane N, Noergaard K, et al. Early age at debut is a predictor of $\mathrm{K}$ steroid dependent and frequent relapsing nephrotic syndrome. Pediatr Nephrol. 2010;25(7):1299-1304.
20. Yap HK, Han EJS, Heng CK, et al. Risk factors for steroid dependency in children with idiopathic nephrotic syndrome. Pediatr Nephrol 2001;16(12):1049-1052.

21. Constantinescu AR, Shah HB, Foote EF, et al. Predicting firstyear relapses in children with nephrotic syndrome. Pediatrics. 2000;105(3pt1):492-445.

22. Sureshkumar P, Hodson EM, Willis NS, et al. Predictors of remission and relapse in idiopathic nephrotic syndrome: A prospective cohor study. Pediatr Nephrol. 2014;29(6):1039-1046.

23. Fujinaga S, Hirano D, Nishizaki N. Early identification of steroid dependency in Japanese children with steroid sensitive nephrotic syndrome undergoing short term initial steroid therapy. Pediatr Nephrol. 2011;26(3):485-486.

24. Takeda A, Takimoto H, Mizusawa Y et al. Prediction of subsequent relapse in children with steroid sensitive nephrotic syndrome. Pediatr Nephrol. 2001;169(11):888-893.

25. Sinha A, Hari P, Sharma PK, et al. Disease course in steroid sensitive nephrotic syndrome. Indian Pediatr. 2012;49(11):881-887.

26. Thabet MA, Salcedo JR, Chan JC. Hyperlipidemia in childhood nephrotic syndrome. Pediatr Nephrol. 1993;7(5):559-566.

27. Ibadin MO, Abiodun PO. Epidemiology and clinicopathologic characteristics of childhood nephrotic syndrome in Benin-City, Nigeria. JPMA. J Pak Med Assoc. 1998;48(8):235-238.

28. Begum A, Rahman H, Hossain MM, et al. Histological variant of nephrotic syndrome with atypical presentation in children. Mymensingh Med J. 2009;18(1):42-46.

29. Srivastava RN, Mayekar G, Anand R, et al. Nephrotic syndrome in Indian children. Archives of disease in childhood. 1975;50(8):626-630.

30. Takeda A, Matsutani H, Niimura F, et al. Risk factors for relapse in childhood nephrotic syndrome. Pediatr Nephrol. 1996;10(6):740-741.

31. Sarker MN, Islam MMSU, Saad T, et al. Risk factor for relapse in childhood nephrotic syndrome - a hospital based retrospective study. Faridpur Med. Coll. J. 2012;7(1):18-22.

32. Kopp JB, Smith MW, Nelson GW, et al. MYH9 is a major-effect risk gene for focal segmental glomerulosclerosis. Nat Genet. 2008; 40(10):1175-1184.

33. Dinc N, Yilmaz E, Bulut IK, et al. The long-term outlook to final outcome and steroid treatment results in children with idiopathic nephrotic syndrome. Ren Fail. 2015;37(8):1267-1272.

34. Wingen AM, Müller-Wiefel DE, Schärer K. Spontaneous remissions in frequently relapsing and steroid dependent idiopathic nephrotic syndrome. Clin Nephrol J. 1985;23(1):35-40.

35. Wynn SR, Stickler GB, Burke EC. Long-term prognosis for children with nephrotic syndrome. Clin Pediatr (Phila). 1988;27:63-68. 